しかし，ビームのモニター特にエネルギー測定に関して は，末だ水層或は等価物質等が必要であり現在の所治療 中に直接モニターする万法はない.

今後の課題としては，ビーム自身の性能改良以外に， 治療の間等の僅かな時間でのエネルギー測定を行うため のビームモニターの簡素化, 更には治療中でのエネルギ

ーモニターの開発である。

考文献

1) 吸収線量の標準測定法，日本医学放射線学会物理部 会編，第 1 版，(1986).

\title{
3. 物理的観点からエネルギー特定の問題点
}

\author{
佐方周防 \\ 千葉県がんセンター物理室
}

\section{1.はじめに}

電子線ビームが人体あるいはファントム等に入射した 場合の深部量百分率，線量分布およびその他の線量の関 するパラメータは，その電子のエネルギーに極めて強く 影響を受ける。よって放射線治療のための線量测定の立 場からは，電子線のエネルギ一をはっきりと定義し，正 しく決定しなければならない。

一般に，加速器中で加速されている電子ビームはほほ 単一エネルギーと考えられるが，このビームがファント ム表面に達する迄に，出射空，スキャタリングフォイル， モニター電離箱, 空気などを通過するため広がりを持っ たエネルギースペクトルとなり，更にファントム中では もっと大きなエネルギーの減衰と広がりおよび角度の広 がりが起こる。このような変化を忠実に考慮した線量推 定は，理論的にも，また実験的にも複雑な要素を抱えて おり簡単に行うわけには奻かない,よって，臨床の場で は実用的な測定および近似計算法が採用されている。

わが国の測定プロトコール（日医放物理学会より発行 されている「放射線治療における高エネルギーX線ちよ び電子線の吸収線量の標準測定法」”。以下，標準測定法 とする）では，電子線のエネルギーパラメータとして，

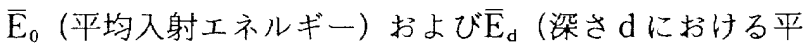
均エネルギー)を用い，その計算を $\mathrm{R}_{50}$ (線量半価深)よ り行うことを勧告している．ただし，これらの值の決定 には末だ問題点の残されているところであり，ここでは エネルギー決定の手順抢よび定数等の選択に関するもの と手順実施上の煩雑さについてのものの 2 種類に分けて 検討する。

\section{2. エネルギー決定手順およびこれに用いる定数}

電子線ビームのエネルギー決定手順および用いる定数 等について，標準測定法と外国のプロトコールを比較す
ると，やや相違が見られる。その主なものをTable 1 に 示す.その差は臨床レベルにおいて要求される精度から みれば無視できるものもあるし，理論および技術の進歩 により新しいデータが加えられた場合もあり，適当な機 関（例えば日医放物理学会の測定委員会）による検討を 待ちたい。また，外国で設計されたコンピュータ治療計 画装置を用いる際は，プロトコールの差により入力すべ き値あるいは得られた結果が標準測定法と異なることも あり得る。ここでは，いくつかの項目につき若干の考察 を述べる。

\section{1 決定すべきエネルギー}

標準測定法では, 電子線エネルギーの基本として, 吸 収線量変換係数 $\mathrm{C}_{E}$ を求めることにのみ目的を限定し, 電子線がファントムや人体の表面に入射するときの平均 エネルギー $\bar{E}_{0}$ だけが記載されている，以前は，表面にお ける最頻エネルギー $\mathrm{E}_{\mathrm{P}, 0}$ も用いられていたが，最新のほ とんどのプロトコールでは， $\mathrm{C}_{\mathrm{E}}$ の决定には $\overline{\mathrm{E}}_{0}$ の使用が 推奨されている. $\mathrm{E}_{\mathrm{P}, 0}$ は, $17 \sim 22 \mathrm{MeV}$ の範囲で $\overline{\mathrm{E}}_{0}$ より $2 \mathrm{MeV}$ 程度大きいことや, $\mathrm{R}_{50}$ より求められた $\overline{\mathrm{E}}_{0}$ でも真 の值よりやや過大評価気味なので, 結局 $(\overline{\mathrm{L}} / \rho)_{\mathrm{n}, \mathrm{a}}$ (水と 空気の平均制限衝突質量阻止能の比）を少なく見積もる ことう，などがその理由である。

ただし， $\mathrm{E}_{\mathrm{p}, 0} に は$ 別の使用目的もあり，外国のプロ卜コ ールでは，(E $E_{P, 0}$ を求めるための）実用飛程 $R_{P}$ が後述の ファントム中の平均エネルギー決定にも用いられている ので，これらの值の定義および決定法が記載されている. また，ややあいまいではあるけれども， $\mathrm{E}_{\mathrm{P}, 0} よ り \overline{\mathrm{E}}_{0}$ を計 算する式も示されている標準測定法の方針は明快で あるが，他のエネルギー表現法についても多少のコメン トが欲しいところである.(電子線エネルギーの定義わよ び性質の詳細については文献を参照されたい、汭)

\section{$2.2 \quad \overline{\mathbf{E}}_{0}$ の求め方}

標準測定法による $\overline{\mathrm{E}}_{0}$ の決定手順では，まず深部量百分 
Table 1 電子線エネルギーの決定における，標準 測定法と他のプロトコールの比較

\begin{tabular}{|c|c|c|}
\hline 頁 目 & 嫖準測定法 & $A A P M^{2}, \quad \triangle A C P^{3.4}$ \\
\hline 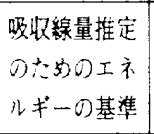 & 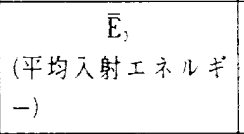 & 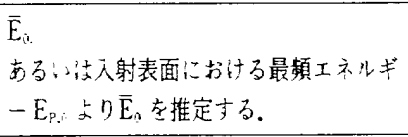 \\
\hline$\overline{\mathrm{E}}_{0 \text { の計算法 }}$ & $\begin{array}{c}\bar{E}_{0}=2.33 R_{5 j} \\
\left(R_{50}: \text { 線量半(酸) }\right.\end{array}$ & 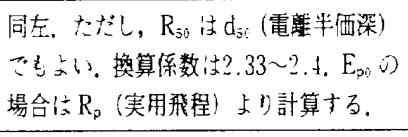 \\
\hline $\begin{array}{l}\text { PDD湖定時 } \\
\text { のビームの発 } \\
\text { 散の補正 }\end{array}$ & 規定無 & 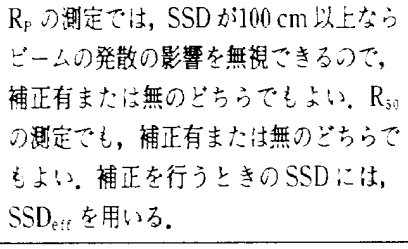 \\
\hline $\begin{array}{l}\text { PDD 眼定時 } \\
の S S D \text { など }\end{array}$ & 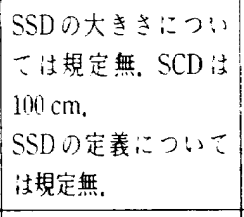 & 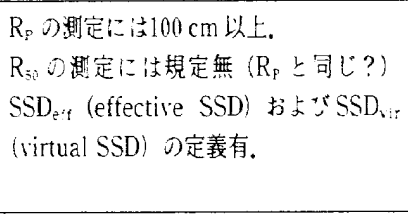 \\
\hline $\begin{array}{l}\text { PDD 澌定時 } \\
\text { の照射野 }\end{array}$ & $d_{5 B}$ の2 倍以上 & 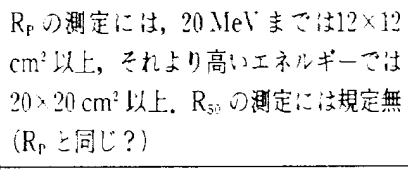 \\
\hline 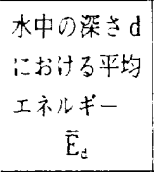 & 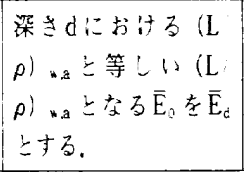 & $\begin{array}{l}\text { Harder の式 } \\
\bar{E}_{\mathrm{c}}=\overline{\mathrm{E}}_{\mathrm{o}}\left(1-d \mathrm{R}_{\mathrm{p}}\right) \\
\text { より求する. }\end{array}$ \\
\hline
\end{tabular}

率（PDD）を決定し，これより $\mathrm{R}_{50}$ を求めて，式

$\mathrm{E}_{0}=\mathrm{C} \cdot \mathrm{R}_{50}$

ここで, C は定数で標準測定法では, 2.33が示されてい

る

により $\mathrm{E}_{0}$ を計算する。

もし測定に指頭形電離箱を用いるならば，得られるの は見掛けの電離量の百分率であり， $\mathrm{R}_{50}$ を求めるにはこ れを梁部電離量百分率 (PDI) に，次いでPDDに変換し なければならない。この変換には $(\overline{\mathrm{L}} / \rho)_{\mathrm{w}, \mathrm{a}}$ および擾乱係 数が必要であり，またそのためには平均入射エネルギー があらかじめ判っていなけれ代ならず, 結局长。の解は直 接法では得られないことになる。この困難を解決するた め，標準測定法では近似法を採用しており，また他のプ ロトコールでは更に簡便的な方法として， $\mathrm{R}_{50}$ の代わり に $\mathrm{d}_{50}$ (電離半価深)を用いることも諗めている2!.ただ し，後者の方法では $\overline{\mathrm{E}}_{0}$ を過少評価することになり， $\mathrm{SSD}=1 \mathrm{~m}$ の测定で, $20 \mathrm{MeV}$ では0.5 MeV, $35 \mathrm{MeV} て ゙$ は3 $\mathrm{MeV}$ 程度 $\overline{\mathrm{E}}_{0}$ を低く見積もることになる6!。

次に，(1)式の換算係数 Cにも多少の異論がある，従 来，ほとんどのプロトコールではBerger \& Seltzer ${ }^{81} に$ より決定された2.33を勧告していたが，最近の Roger ら のモンテカルロ計算によれば，臨床に用いられる電
子線のエネルギーの範囲では，この係数はもう少し大き い值になることが報告されている．Fig.1に彼等によっ て示された $\overline{\mathrm{E}}_{0}$ と $\mathrm{R}_{50}$ の比のエネルギーによる変化を示 寸.またHPAのプロトコールでは,この換算係数として

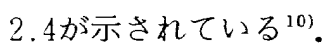

正確な電子線エネルギーを求めようとするならば，標 準测定法に示された近似法を用い，(1)式の換算係数とし て Fig. 1 の值を用いなければならないが，やや手順が煩 雑になることは否めない.

\section{3 ビームの発散の補正}

放射線は，発散により距離の逆自乗に比例して減衰す るので, SSDが異なれば PDD の形状も変化する。よっ て， $\mathrm{R}_{50}$ や $\mathrm{R}_{\mathrm{P}}$ などの值はビームの発散を補正した PDD より求めなければならない。この補正には，ファントム 中の測定值に対し

$$
\begin{aligned}
& \frac{\left(\mathrm{SSD}_{\mathrm{eff}}+\mathrm{d}\right)^{2}}{\left(\mathrm{SSD}_{\mathrm{eff}}\right)^{2}} \\
& \text { ここで, } \\
& \mathrm{SSD}_{\text {eff }} \text { : effective SSD (後述) } \\
& \mathrm{d} \text { : ファントム中の深さ }
\end{aligned}
$$

を乗ずる、ただし，AAPM のプロトコールでは，SSDが $100 \mathrm{~cm}$ 以上なら,この補正による $\mathrm{R}_{\mathrm{P}}$ の変化は $\mathrm{E}_{\mathrm{P}, 0}$ の决 定に対し臨床上有意ではなく, 補正を行っても行わなく てもよいとしている． $\mathrm{R}_{50}$ の決定についても，SSDの制 限を除き同様である 関する記述は特に無いが，大きいSSDならばその影響 は無視できると考えられる。

\section{$2.4 \mathrm{SSD}$ (線源表面間距離)}

電子線ビ一ムは, X線と異なり, 特定の点(線源, source) より放出されるわけではないので, SSD を定義すること が難しい. Dosimetryの立場からは, virtual SSD

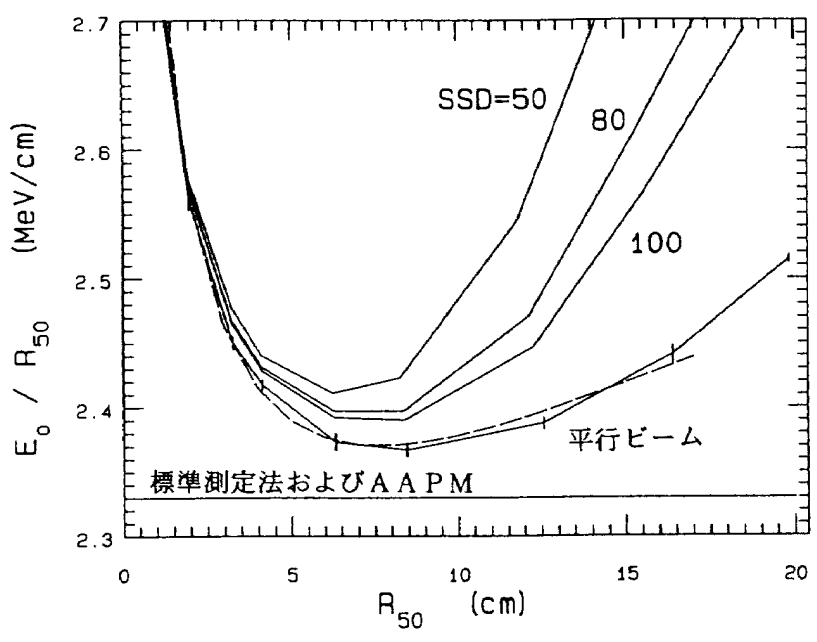

Fig.1 モンテカルロ計算による, 種々のSSDに ついての, $\mathrm{R}_{50}$ より $\mathrm{E}_{0}$ への換算計数 ${ }^{8)}$. 一定 值は，AAPM および標準測定法による勧 告值. 
$\left(\mathrm{SSD}_{\mathrm{vir}}\right)$ および effective $\mathrm{SSD}\left(\mathrm{SSD}_{\mathrm{eff}}\right)$ の 2 つの概念 が用いられているが6), 実際の臨床に近い状態で決定で きるのは後者である，前項で述べた，ビームの発散の補 正に用いられるのも SSD efr である。ただし, $\mathrm{SSD}_{\mathrm{efr}}$ はエ ネルギーおよび照射野によって変化するので, 臨床上必 要な範囲について全てこれを測定しておかなければなら ない.

$\mathrm{SSD}_{\text {eff }}$ を求めるには, 線量計をピーク深に置き, 照射 筒とファントム間の間隔 (gap) を 0 より $20 \mathrm{~cm}$ 程度まで 変えながら数点の線量を測定する. 電子線ビームが逆自 乗則に従うなら

$$
\frac{\mathrm{Q}_{0}}{\mathrm{Q}_{\mathrm{g}}}=\frac{\left(\mathrm{SSD}_{\mathrm{eff}}+\mathrm{d}_{\mathrm{m}}+\mathrm{g}\right)^{2}}{\left(\mathrm{SSD}_{\mathrm{eff}}+\mathrm{d}_{\mathrm{m}}\right)^{2}}
$$

$$
\text { ここで }
$$

$\mathrm{Q}_{0}$ : gap が0のときの線量

$\mathrm{Q}_{\mathrm{g}}: \operatorname{gap}$ が $\mathrm{g}$ のきの線量

$\mathrm{d}_{\mathrm{m}}:$ ピーク深の值

$\mathrm{g}$ : gapの大きさ

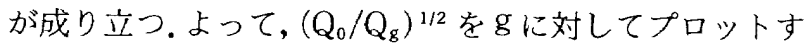
れば直線となり，その傾斜 $\mathrm{a}$

$$
\mathrm{a}=1 /\left(\mathrm{SSD}_{\mathrm{eff}}+\mathrm{d}_{\mathrm{m}}\right)
$$

で表される。よって, $\mathrm{SSD}_{\mathrm{eft}}$ は

$\mathrm{SSD}_{\mathrm{eff}}=1 / \mathrm{a}-\mathrm{d}_{\mathrm{m}}$

より得られる"1).

PDI あるいはPDDを測定するための距離として， AAPM では ( $\mathrm{R}_{\mathrm{P}}$ 決定用に) $100 \mathrm{~cm}$ 以上の $\mathrm{SSD}$ が，標準 測定法では $100 \mathrm{~cm}$ 以上の $\mathrm{SCD}$ が勧告されている. 通常 の医療用加速器では, 照射筒の先端あるいは定格治療距 離をファントム表面とするので，この点での $\mathrm{SSD}_{\mathrm{eff}}$ を チェックしておく必要があろう。

\section{5 照 射 野}

電子線の PDD は，照射野の形状および大きさによっ ても大きく変化する。これはファントム中における電子 の側方への散乱によるもので, PDD の值は照射野が大き くなるにつれ上昇するが，側方散乱電子が平衡状態にな れば一定となる，ICRU ${ }^{6 /}$ は，円形照射野の直径が $\mathrm{R}_{\mathrm{P}}$ 以 上なら PDDの変化を無視できるとしている．各プロト コールによる照射野の勧告值は Table 1 に示したが，実 質的に ICRU よりずっと大きい。標準測定法を AAPM (=NACP) と比較すると，14〜20 MeV および $24 \mathrm{MeV}$ 以上の範冊では前者が大きく，それ以外では後者の方が 大きい.(1)式は広いビームについてたてられた式であり， エネルギー推定のための PDD 測定には，ファントム内 の側方散乱電子の平衡を保つよう十分大きな照射野を用 いなければならない.

\section{6 ファントム中の平均エネルギー}

電子線の出力および PDD の測定に電離箱を用いるな らば，擾乱係数や $(\overline{\mathrm{L}} / \rho)_{\mathrm{w}, \mathrm{a}}$ を決定するために，ファント 厶内の測定位置（梁さd）における平均エネルギー $\overline{\mathrm{E}}_{\mathrm{d}}$ が 必要である. AAPM およびNACP のプロトコールで は， $\overline{\mathrm{E}}_{\mathrm{d}}$ を求める式として

$\overline{\mathrm{E}}_{\mathrm{d}}=\overline{\mathrm{E}}_{0}\left(1-\mathrm{d} / \mathrm{R}_{\mathrm{P}}\right)$ が用いられている.

この式は，電子線スペクトルの平均エネルギーが梁さ

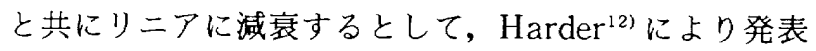
されたが，ファントム内部では散乱により(6)式より得ら れた值よりも更に低くなることが指摘されている7゙.川 島ら”は, Berger ら $ら^{8)} の(\overline{\mathrm{L}} / \rho)_{\mathrm{w}, \mathrm{a}}$ の表より $\overline{\mathrm{E}}_{\mathrm{d}}$ を評価す ることを提案した。すなわち, Berger らの表ではいくつ かの $\overline{\mathrm{E}}_{0} に つ い て ， そ の \mathrm{E}_{0}$ の電子が水中に入射したとき の $(\overline{\mathrm{L}} / \rho)_{\mathrm{w}, \mathrm{a}}$ の変化が与えられている. よって, ある梁さ $\mathrm{d}$ における $(\overline{\mathrm{L}} / \rho)_{\mathrm{w}, \mathrm{a}}$ に等しい $(\overline{\mathrm{L}} / \rho)_{\mathrm{w}, \mathrm{a}}$ を持つ $\overline{\mathrm{E}}_{0}$ を，そ の梁さの $\overline{\mathrm{E}}_{\mathrm{d}}$ とする.標準測定法では，この方法による $\overline{\mathrm{E}}_{\mathrm{d}}$ の決定が勧告されている.

川島らの方法と Harder の式の差は, エネルギーが高 くなるにつれかなり大きくなるので, 外国のプロトコー ルによる計算結果を使用するときは注意しなければなら ない。

\section{3. エネルギー測定の実施とエネルギーモニタ}

\section{1 エネルギー測定実施の背景}

現在, 放射線治療機器に対する品質管理 $(\mathrm{QC})$ の励行 が各方面より指摘されており，定期的な作業はなるべく 簡便且つ短時間に行なえることが望ましい，日本放射線 腫淘学会他より発表された「外部放射線治療装置の保守 管理プログラム」13)では，エネルギーのQCには直接子 れていないが, 次の 2 つの項目が電子線のエネルギーに 関連する。

ひとつは電子線の深部線量曲線のチェック (点検頻度 1 年, 許容誤差士 $2 \%)$ で, これにはエネルギーの推定 が必要不可欠であり，標準測定法に準ずる外はない。実 行手順はかなり煩雑なので, 適当なコンピュータソフト などを用いて作業効率の向上を図るべきである。いくつ かのパーソナルコンピュータ用ソフトが公開されており 利用できる ${ }^{14,15)}$.もうひとつは深部線量または校正梁と の線量比 (点検頻度 1 月, 許容誤差 $\pm 2 \%$ or $2 \mathrm{~mm}$ ) で, 通常 $80 \%$ あるいは $30 \%$ 深部の線量が校正点の線量と 比較される. 本項目は, ある固定点の深部線量の変動を 測定することであり，直接エネルギーを推定することは できないが, ビームのエネルギーが変化すればその影響 を検出できる，ただし，このやり方では，装置の公称工 ネルギーを変える毎に, 基準点の線量と深部線量の双方 を測定しなければならない。現在，エネルギーのルーチ ンのチェック用の测定器が入手できるようになり，また 簡易測定法の報告もあるので16)，作業の省力化を図る可 能性はあると考えられる。 
最近, 電子線エネルギーの QC 用ツールとして, PTW より Geske type3405エネルギーモニタ (以下, エネルギ ーモニタとする）が市販された。エネルギーモニタは 5〜25 MeV の電子線ビームのエネルギーの確認を目的 とするもので, 前項で述べたようなファントム中での PDD の測定といった方法と比較すると,簡便で且つ時間 の節約が期待できる ${ }^{17)}$. 性能および使い勝手などについ てテストする機会があったので以下に報告する。

\section{2 エネルギーモニタによる電子線エネルギーの推 定}

\section{2 .1 構造と原理}

エネルギーモニタの外観および構造を Fig. 2 および 3 に示す. 形状は, 長さ $9 \mathrm{~cm}$, 直径 $5.5 \mathrm{~cm}$ の円筒形で, 内部に 9 個の平行平板電離箱が階層状に重ねられている. また，全ての電離箱の集電極は電気的に接続されている. 各電離箱は，それぞれ $5 \mathrm{~mm}$ の $\mathrm{Al}$ の吸収体で隔てられ ており, 更に最初の電離箱の前に $5 \mathrm{~mm}$, 最後の電離箱の 後に $7 \mathrm{~mm}$ の吸収体があるので, $\mathrm{Al}$ の厚みは合計 5.2 $\mathrm{cm}$ となり, 全部で $20 \mathrm{MeV}$ 以上の電子線を吸収すること ができる.Fig. 4 のような配置で, 電離箱に垂直な方向よ

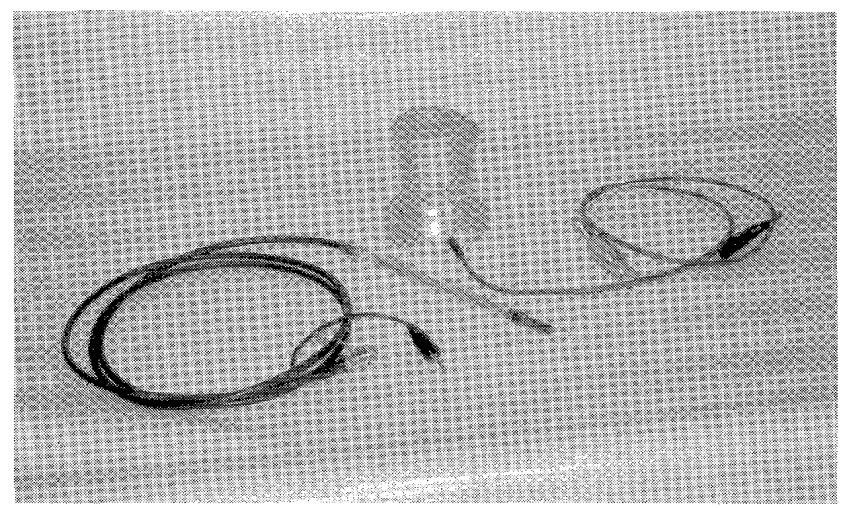

Fig. 2 エネルギーモニタの外観. 図中の指頭型電 離箱は，エネルギーモニタの校正に用いた 基準線量計（応用技研製 C110型電離箱）で ある。

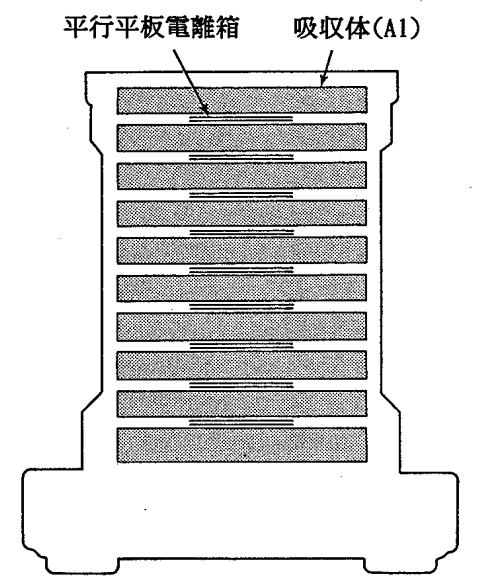

Fig.3 エネルギーモニタの構造. 電子線ビームの 照射は図の上方より行う。

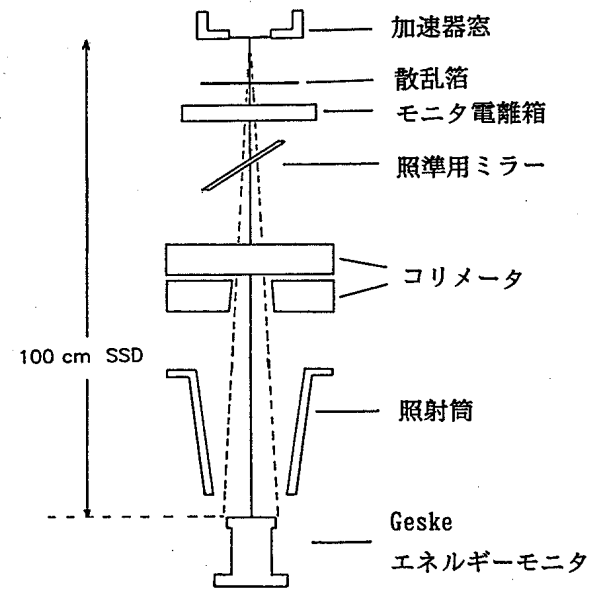

Fig.4 エネルギーモニタを照射するときの配置

Table 2 エネルギーモニタの校正に用いた装置 および条件

\begin{tabular}{|c|c|}
\hline 治療用加速器 & Siemens MEVATRON KD class \\
\hline 電子線公称エネルギー & $6,9,12,15,18,21 \mathrm{MeV}$ \\
\hline 照射野およびSSD & $\begin{array}{l}14 \times 14 \mathrm{~cm}^{2} \text { (可変式コリメー夕使用) } \\
\text { および } 100 \mathrm{~cm} \text { (定格治療距離) }\end{array}$ \\
\hline 基準線量計 & 応用技研C110電離箱\#428 \\
\hline エネルギーモニタ & PTW Geske type $3405-052$ \\
\hline $\begin{array}{c}\text { 電位計执よび } \\
\text { 印可電圧 }\end{array}$ & $\begin{array}{l}\text { 応用技研AE132a\#2002106, }-400 \mathrm{~V} \\
\text { (基準線量計およびエネルギーモ二タの双 } \\
\text { 方に同じ電位計および印可電圧を用いる) }\end{array}$ \\
\hline
\end{tabular}

り電子線を入射した場合，粒子フルーエンスが同じなら ば全電離箱より発生する電荷はビームの透過量に比例す るので，エネルギーの高いビームほど電離電流が増すこ とになる.よって, 加速器の公称エネルギー毎に， $\mathrm{R}_{50}$ よ り求めた $\mathrm{E}_{0}$ とこの電離電流をあらかじめ関係づけてお けば，その以後の日常のエネルギーのチェックはエネル ギーモニ夕（十基準線量計）への照射だけで冏み，PDD の測定は不要である。

\section{2 .2 校正法}

上述のように，エネルギーモニタを使用するときは， 各施設の加速器で, 一定の粒子フルーエンスに対する電 離量と $\mathrm{R}_{50}$ の関係を前もって校正しておく必要がある. 今回のテストにおいて，校正に用いた装置および条件を Table 2 に示す. 先ず, 全てのエネルギーについて, 同じ 粒子フルーエンスとなるビームを決定しなければならな い. エネルギーモニタのマニュアルには，加速器モニタ あるいは基準線量計の一定值をこれに当てることが示さ れているが, 使用した加速器のモニ夕校正值はエネルギ 一により大きく異なるので，基準線量計を用いることに した。ただし，この場合，マニュアルでは基準線量計を $0.5 \mathrm{~mm}$ 厚アクリル中で測定するための専用治具が必要 とされているが，入手できなかったので，代替法として 


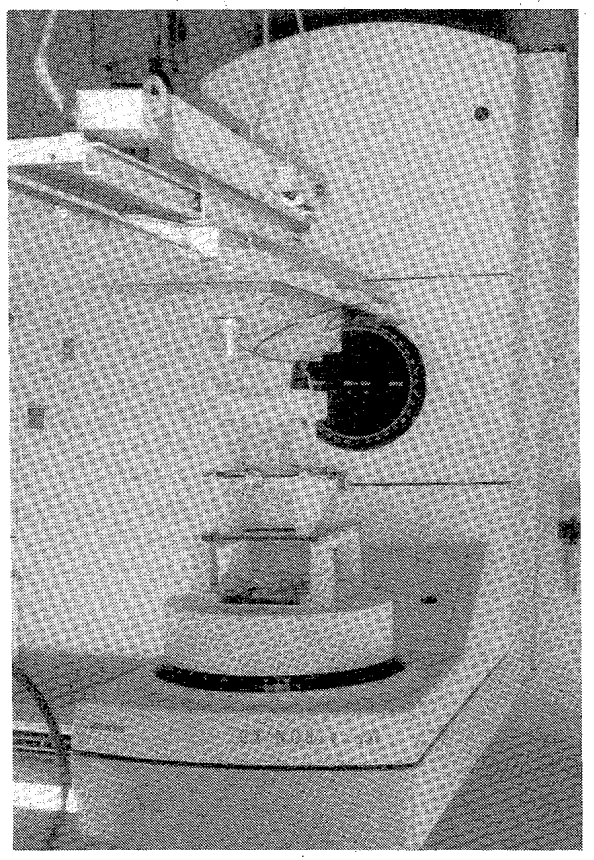

Fig.5 エネルギーモニタを校正するときの測定器 の配置.エネルギーモニタと基準線量計用 の Mix DPファントムは治療用ベッド上 に並べておく．照射野は電子線用可変コリ メータを用いて決める。

MixDP 中 $1 \mathrm{~cm}$ 深さの点に線量計を設置した。

エネルギーモニタおよび基準線量計用の $\mathrm{MixDP}$ は,

Fig. 5 に示すように, 双方共治療用ベッドの上に置く.工 ネルギーモニタのビーム入射面と MixDP の表面はいず れも定格治療距離とした。各公称エネルギー毎に，一定 の加速器モニタ值で，エネルギーモニタに照射を行い, 次いでベッドを平行移動して基準線量計に照射する。こ のときのエネルギーモニタと基準線量計の読みの比が, 一定粒子フルーエンス当りのエネルギーモニタの電離を 表すとする， $\mathrm{R}_{50}$ は，本テストのためには特に測定せず， 各公称エネルギー毎に，これまでの QC 作業に扔いて $14 \times 14 \mathrm{~cm}^{2}$ およびそれ以上の照射野について得られた 結果の平均值を使用した. $\overline{\mathrm{E}}_{0}$ は，これより(1)式を用いて 計算する。

\section{2 .3 結果}

各公称エネルギーに対する $\overline{\mathrm{E}}_{0}, \mathrm{R}_{50}$ およびエネルギー モニタと基準線量計の読みの比を Table 3 に示す.また, Fig. 6 はこの比と $\mathrm{R}_{50}$ の関係である. 測定は 1 週おきに 3 回行った. 各回の結果は 5 個以上の測定值の平均であ るが，測定器の安定性は極めてよく，ばらつきは電位計 の最終桁の $1 \sim 2$ digit 程度であった. エネルギーモニ夕 と基準線量計の読みに対する大気補正は，双方が開放型 電離箱なので省略できる。再結合損失の補正は基準線量 計についてのみ行った。

Table 3 より，エネルギーモニタと基準線量計の読み の比と $\mathrm{R}_{50}$ の関係を直線回㷌法で求めると
Table 3 加速器の公称エネルギーに対する, $\mathrm{E}_{0}$, $\mathrm{R}_{50}$ およびエネルギーモニタと基準線量 計の読みの比. 比は, 独立した 3 回の測 定の結果が示してある。

\begin{tabular}{ccccccc}
\hline \hline 公称エネルギー & \multicolumn{1}{c}{$\mathrm{E}_{0}$} & \multicolumn{1}{c}{$\mathrm{R}_{50}$} & \multicolumn{3}{c}{$\begin{array}{c}\text { エネルギーモニタ } \\
\text { と基準線量計の比 }\end{array}$} \\
\hline $6 \mathrm{MeV}$ & $5.56 \mathrm{MeV}$ & $2.40 \mathrm{~cm}$ & 1.74 & 1.75 & 1.75 \\
9 & 8.16 & 3.55 & 3.03 & 3.03 & 3.04 \\
12 & 11.29 & 4.92 & 4.43 & 4.43 & 4.42 \\
15 & 14.07 & 6.15 & 5.56 & 5.59 & 5.60 \\
18 & 16.95 & 7.31 & 6.44 & 6.48 & 6.49 \\
21 & 17.89 & 7.74 & 6.95 & 6.99 & 6.99 \\
\hline
\end{tabular}

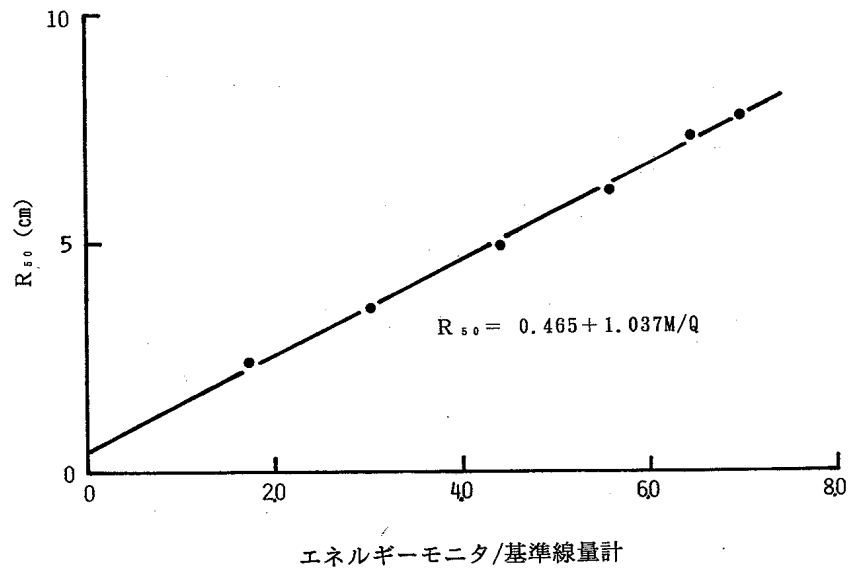

Fig.6 直線回帰によるエネルギーモニタの校正值 線 $\left(\mathrm{R}_{50}\right.$ に対する一定粒子フルーエンス当 たりのエネルギーモニタの值. 一定粒子フ ルーエンスには基準線量計の值を当てる。）

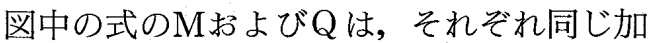
速器モニ夕值に対するエネルギーモニタと 基準線量計の読みである。

$\mathrm{R}_{50}=(0.465 \pm 0.073)+(1.037 \pm 0.014) \mathrm{M} / \mathrm{Q}$

ただし， $\mathrm{M}$ はエネルギーモニタの読み， Q は基準線量 計の読みである。

が得られた。平均悞差は $0.114 \mathrm{~cm}$ (エネルギーに換算す れば約 $0.26 \mathrm{MeV}$ ), 決定係数（相関係数の自乗）は $0.997 ， \mathrm{R}_{50}$ の実測值と期待值の差は最大で $1.5 \mathrm{~mm}$ であ った。以上の結果より，ここで用いた粒子フルーエンス の決定法でも，エネルギーモニタの測定值と $\mathrm{R}_{50}$ の間の 良好な直線関係が得られることが判る。また, 性能的に, エネルギーモニタは, JASTRO の線量管理プログラムに 示された許容誤差士 $2 \mathrm{~mm}$ の範囲で $\mathrm{R}_{50}$ の変動を検出で きるものと考えられる。

\section{2 .5 問題点}

エネルギーモニタは, その内部に平行平板形電離箱を 9 個も内蔵しており, 保守にやや難があるのではないか と思われる，また，全てのエネルギーのビームについて， 同じ粒子フルーエンスを正確に決定する必要もある。初 めてエネルギーモニタを使用する際は, 最初に一定の粒 
子フルーエンスに対する電離量と $\mathrm{R}_{50}$ の関係を校正して おかなければならないが，ルーチンのエネルギーのチエ ックの精度は,この校正条件の再現性に大きく依存する. 3.2.2で述べたような, 基準線量計の測定と同時にエネル ギーモニタの照射も行う方法なら，测定条件の再現性と いう点では問題はない。一方，加速器のモ二夕校正值を 使用する場合は，そのモニタシステムの変動がエネルギ 一モニタの測定精度に影響を与える. 加速器のモニタシ ステムの性能がよく，またモ二夕校正が頻繁に精度よく 行われてい㞦ば，これを基準として粒子フルーエンスを 決めることは可能であろう。

\section{4.まとぬ}

1. 電子線のエネルギー決定法は日医放物理学会の標 準測定法に記載されているが，やや不充分な点もあり注 意を要する.将来の同学会測定委員会などによる検討を 待ちたい.

2.放射線治療に用いられる電子線のエネルギーは比 較的広い範用に丽るので，標準測定法に基づいた測定を 行う際は，適当なコンピュータソフトなどを使用し手順 の省力化を図るべきである。

3. 加速器の高度な QAにおいて, 毎日のエネルギー チエックが要求されるような場合には，エネルギーモ二 タのような測定器は，高価ではあるが，充分な精度を有 し時間と労力の節約に有効であろう。

\section{謝辞}

電子線エネルギーの測定につき，発表の機会を与えて下さ つた計測部会の前越久会長に感謝します。また, PTW 3405型 エネルギーモニタのテストについて，便宜を図っていただい た東洋メディック林ならびに千葉県がんセンタ一放射線治療 部の技師諸兄にも厚くお礼申し上げます。

\section{参考文献}

1) 日本医学放射線学会物理部会(編)：放射線治療にお ける高エネルギーX線および電子線の吸収線量の標 準測定法。通商産業研究社，東京，(1989）。

2) Khan FM, Doppke KP, Hogstrom KR, et al.: Clinical electron-beam dosimetry; Report of AAPM Radiation Therapy Committee Task Group No. 25. Med. Phys., 18, 73-109, (1991).

3) Nordic Association of Clinical Physics (NACP) : Procedures in external radiation therapy dosimetry with electron and photon beams with maximum energies between 1 and $50 \mathrm{MeV}$. Acta Radiol. Onc., 19, 55-79, (1980).

4) Nordic Association of Clinical Physics (NACP) : Electron beams with mean energies at the phan- tom surface below $15 \mathrm{MeV}$. Acta Radiol. Onc., 20 , 401-415, (1981).

5) Johansson KA, Srensson H, : Liquid ionization chamber for absorbed dose determinations in photon and electron beams. Acta Radiol. Oncol., 21, 359-367, (1982).

6) International Commission on Radiation Unit and Measurement (ICRU) : Radiation dosimetry : Electrons with initial energies between 1 and 50 MeV. ICRU Report 35, ICRUM, Bethesda. (1984).

7）川島勝弘，星野一雄，平岡 武：放射線治療のため の線量測定.その 2 , 電子線の平均エネルギーの決 定法. 放治システム研究，2，261-269，(1985)。

8) American Association of Physicists in Medicine (AAPM), RTC Task Group 21: A protocol for the determination of absorbed dose from highenergy photon and electron beams, Med. Phys., 10, 741-771, (1983).

9) Rogers DWO, Bielajew AF : Differences in electron depth-dose curves calculated with EGS and ETRAN and imploved energy-range relationships. Med. Phys., 13, 687-691, (1986).

10) Hospital Physicists Association (HPA) : Code of practice for electron beam dosimetry in radiotherapy. Phys. Med. Biol., 30, 1169-1194, (1985).

11) Khan FM, Sewchand W, Levitt SH : Effect of air space on depth dose in electron beam therapy. Radiology, 126, 249-259, (1978).

12) Harder D: Energiespektren Schneller Elecktronen in Verschiedenen Tiefen. In Symposium on High-Energy Electrons, Zuppinger A \& Poretti G, Eds., Springer-Verlag, Berlin, 260, (1965).

13）日本放射線腫湟学会研究調査委員会 (編)：外部放射 線治療装置の保守管理プログラム, 通商産業研究社, 東京, (1992).

14）川島勝弘, 佐方周防, 星野一雄, 他：放射線治療の ための線量測定，その 6 。吸収線量の標準測定法の 実際. 放治システム研究，4，191-211，(1988）.

15）石崎邦明：高エネルギーX線および電子線の吸収線 量計算プログラム。日医放物理会誌，9，153-156， (1989).

16）津坂昌利，青山隆彦，小山修司，他：電子線エネル ギー測定のためのシンチレーションファイバー線量 計の開発。日放技会誌，51，1560，(1995).

17) Ramsay EB, Reinstein LE, Meek AG: Tests of an electron monitor for routine quality control measurements of electron energies. Med. Phys., 